\title{
Self-help groups in empowering women: A study in Udaipur and Jhalawar districts of Rajasthan
}

\author{
VISHAKHA BANSAL*, VANDANA JOSHI, PURVA DAYYA ${ }^{1}$ AND SUBHASH MEENA ${ }^{2}$ \\ AICRP - HECM, College of Home Science, Maharana Pratap University of Agriculture and Technology, \\ UDAIPUR (RAJASTHAN) INDIA \\ ${ }^{1}$ College of Home Science, MaharanaPratap University of Agriculture and Technology, UDAIPUR \\ (RAJASTHAN) INDIA (Email : purva.mpuat@ gmail.com) \\ ${ }^{2}$ Department of Soil Science, Rajasthan College of Agriculture, Maharana Pratap University of \\ Agriculture and Technology, UDAIPUR (RAJASTHAN) INDIA (Email : subhmeena@ yahoo.com)
}

\begin{abstract}
The study was conducted in Udaipur and Jhalawar district of Rajasthan, to know the Empowerment status of SHG members. Total 1123 groups were registered during year 2008-09 by different forming agencies. In which, 102 SHGs were selected from NABARD, ICDS, DRDA and SAUs.Major finding revels that comparison of empowerment data before joining the SHGs, there was slight change in status of women, as before joining the SHG there were 33 office bearers who were found in the low empowerment category of legal and political empowerment however, after becoming the member of SHGs the percentage decreased upto 10 per cent and only 24 office bearers remained in this category.
\end{abstract}

KEY WorDs : Self-help groups, Empowerment, Empowering women

View Point Article : Bansal, Vishakha, Joshi, Vandana, Dayya, Purva and Meena, Subhash (2017). Self-help groups in empowering women: A study in Udaipur and Jhalawar districts of Rajasthan. Internat. J. Home Sci. Extn. \& Comm. Manage., 4 (1): 57-60. DOI : 10.15740/HAS/IJHSECM/4.1/57-60.

Article History : Received : 03.11.2016; Accepted : 28.12.2016

* Author for correspondence : (Email : bvishakha29@yahoo.com) 